\title{
ARGENTINIETIŠKOJO TANGO IR FLAMENKO ŠOKIŲ POVEIKIO TYRIMO METODOLOGIJA: KARINIO PERSONALO ESTETINIS IR EMOCINIS PATYRIMAS
}

\author{
Dr. Laima Sapežinskienè \\ Lietuvos sveikatos mokslu universiteto Medicinos akademijos Neuromokslų institutas, \\ Elgesio medicinos laboratorija
}

Jurgita Kuliešienè

Nepriklausoma tyrëja

\begin{abstract}
Anotacija. Straipsnyje pateikta tyrimo metodologija, grịsta moksliniu tyrimu rezultatais, kad „, šokis gali paveikti estetiškai ne tikji atliekančius, bet ir stebinčius (auditorija) “ (Vukadinović, 2010; Vukadinović \& Marković, 2011).

Tyrimo problema - nors atliekant tyrimus gaunama vis daugiau ịrodymu, kad šokis ir šokio judesiai skatina smegenu veikla ir didina jų neuroplastiškuma, taip pat kad šokant patiriamas estetinis judesiu ir šokio išgyvenimas per propriocepcinius jutimus, jaučiamus kūne, raumenyse, sausgyslèse, sq̨nariuose, t. y. kinestetinèje, vestibuliarinèje sistemoje (Vukadinović \& Marković, 2011), neaišku, ar galima taikyti ne tik šoki, bet ir jo stebejjima karinio personalo reabilitacijai. Mokslinio tyrimo klausimas: koks büna karinio personalo, išgyvenusio stresinius, trauminius jivykius, estetinis ir emocinis patyrimas, kai jis atlieka ar stebi argentinietiškaji tango ir flamenko siekiant edukaciniu ir (ar) reabilitacijos tikslu?? Iki šiol nebuvo žinoma, kad tokia metodologija būtu taikyta karinio personalo po stresiniu, trauminiu jvykiu edukacijai ar reabilitacijai paspartinti. Tyrimo objektas - karinis personalas, patyręs trauminius juvkius, kuriam diagnozuotas arba nediagnozuotas potrauminio streso sindromas. Aprašyti tyrimo metodai ir tyrimo instrumenta skirti nustatyti, koki poveiki argentinietiškasis tango ir flamenko turi tyrimo dalyviu pasitenkinimui savo fizine, psichoemocine ir socialine savijauta ir kokios sąsajos su ju estetiniu ir emociniu patyrimu atsiranda šiuos šokius atlikus ar stebejus.
\end{abstract}

Reikšminiai žodžiai: karinis personalas, estetinis ir emocinis patyrimas, argentinietiškasis tango (AT), flamenko (F), pasitenkinimas savijauta.

\section{Ivadas}

Labiausiai tikètina, kad probleminio elgesio apraiškų padaugèja, kai karinis personalas patiria stresą (The Context of Military Environments, 2014). Karyba pagrįstai priskiriama prie pačių sudètingiausių veiklos rūšių. Stresą gali sukelti dau- 
gelis šaltinių: karinio gyvenimo įtampa ir spaudimas, asmeninès problemos, santykiai su šeima namuose nedarbingumo metu, po traumų ar misijų, išèjus ị pensiją ir tais atvejais, kai turima per daug laisvo laiko. Karinis personalas dèl savo darbo specifikos sudaro socialinę grupę, izoliuotą nuo šeimos, artimųjų ir draugų, taip pat išorinių informacijos šaltinių. Sugrịžus namo, jiems tenka adaptuotis, prisitaikyti prie ịprasto gyvenimo ir jo ritmo, keisti savo ịpročius, ir tai vẻl sukelia nemažai socialinių ir psichologinių problemų (Hatch et al., 2013). Nedaug tyrimų atlikta aiškinantis, kaip išgyvena mentaliai ir emociškai nuo karinio gyvenimo išsekęs, emociškai pervargęs, dèl įvykių namuose sunerimęs karinis personalas (The Context of Military Environments, 2014). Galima teigti, kad karinis personalas susiduria su baime, nerimu, indukuojančiais fiziologini nervų simpatinès sistemos suaktyvejjimą, nervinę ịtampą, pastangas kovoti ar atsitraukti ir siekị suvaldyti šiuos procesus (Burrell et al., 2006). Toks emocinių veiksnių poveikis yra perkeliamas ị taikaus socialinio gyvenimo tarpsni, nes yra paveiktas dar ne visai suvoktos trauminès patirties ir vidinio pasipriešinimo, neleidžiančio atsiskleisti.

Mokslinès tyrimų apžvalgos rodo, kad karo tarnybos iššūkių padariniai turètų būti kompensuojami taikant palaikomają kultūrą, kuri, remiantis dabartine ịrodymais pagrịsta praktika, tokia kaip meno terapija (pvz., taikant šoki), gali būti naudojama kaip gydymo būdas. Jei dabartiniai karo tarnybos kariai ir veteranai būtu įtraukti i meno terapijos programas kuo anksčiau po to, kai jiems diagnozuotas, pavyzdžiui, potrauminis streso sindromas (PTSS), būtų mažesnè rizika patirti stipriau pasireiškiančius PTSS simptomus (Iversen et al, 2009; Iversen et al., 2010; Ramirez, Erlyana, \& Guilliaum, 2016).

Tyrimo problema. Nors atliekant tam tikrus tyrimus gaunama vis daugiau įrodymų, kad šokis ir šokio judesiai skatina smegenų veiklą ir didina jų neuroplastiškumą, taip pat kad šokant patiriamas estetinis judesių, šokio išgyvenimas per propriocepcinius jutimus, jaučiamus kūne, raumenyse, sausgyslèse, sąnariuose, t. y. kinestetinejje, vestibuliarinejje sistemoje (Vukadinović \& Marković, 2011), neaišku, ar galima taikyti karinio personalo reabilitacijai ne tik šoki, bet ir jo stebejjimą.

Tyrimo objektas. Planuojama ị tyrimą ịtraukti karini personalą, t. y. apie 60 (18-70 metų) tiriamujų̧, patyrusių trauminių ịvykių (dalyvavusių mūšiuose, karinèse misijose ir kt.), kuriems buvo diagnozuotas arba nediagnozuotas potrauminio streso sindromas. Visi tyrimo dalyviai bus supažindinti su tyrimo informacine anketa ir patys nuspręs, ar nori dalyvauti tyrime.

Straipsnio tikslas - pateikti tyrimo metodologiją, siekiant atsakyti į mokslinio tyrimo klausimą: koks karinio personalo, patyrusio stresinius, trauminius ivvykius, estetinis ir emocinis patyrimas, kai jis atlieka ar stebi AT ir F šokius reabilitacijos ir (ar) edukaciniais tikslais?

Uždaviniai: 1) sukurti tyrimo metodologiją; 2) aprašyti tyrimo instrumentą, skirtą nustatyti, kokị poveikį AT ir F šokiai turi tyrimo dalyvių fizinei, psichoemocinei ir socialinei savijautai prieš ir po AT ir F šokių ar stebejjus juos atliekant; 2) aprašyti tyrimo instrumentą, skirtą tyrimo dalyvių estetiniam ir emociniam patyrimui 
ịvertinti po AT ir F ar stebejjus juos atliekant; 3) rasti sąsajas tarp estetinio šokio patyrimo ir emocinès identifikacijos ir pasitenkinimo savo fizine, psichoemocine ir socialine savijauta.

\section{Metodologija ir metodai}

Metodologija ir metodai grịsti mokslinių tyrimų rezultatais, kad „šokis gali paveikti estetiškai ne tik atliekančius šokị, bet ir ji stebinčius (auditoriją)“ (Vukadinović, 2010; Vukadinović \&Marković, 2011). Tyrimų rezultatai rodo, kad šokio metu gali būti išreiškiamos emocijos, pvz., liūdesys, pyktis, laimè ir baimè. Šokio raiška gali būti veiksminga tyrimo priemonè, padedanti pastebèti, kaip siejasi atliekančio šokị asmens emocijų raiška su jo intencijomis ir estetinèmis judesių savybėmis (Sevdalis \& Keller, 2011). Karinio personalo, patyrusio stresinius, trauminius ìvykius, reabilitacija ir (ar) edukacija iš esmès susijusi su asmens fizinio, psichinio, emocinio ir socialinio funkcionalumo atkūrimu. Išgyventų traumų metu dažnai prarandamas gebejjimas autentiškai save išreikšti, nes asmenys po traumos jaučiasi atsiriboję nuo savęs ar gyvenimo, dažnai galią sieja su smurtu, o judant juos gali užplūsti stiprios emocijos (Winters, 2017; Koch et al., 2019). Išgyvenusiems traumą tinka šokti $\mathrm{F}$ ir klausytis muzikos, nes tai veikia igalinančiai, suteikia pasididžiavimo savimi, gerovès pojūti (Sapežinskienè \& Prijmenko, 2013; Prijmenko, 2013; Koch et al., 2019). Pasirenkame F ir AT, nes abiejų šokių terapinis poveikis jau buvo nagrinètas ịvairiose studijose anksčiau. Buvo nustatyta, kad F yra holistinis šokis, nes apima intelekto, fizinius, emocinius, dvasinius savasties aspektus vienoje veikloje (Caltabiano, 2009; Vargas, 2010; Sapežinskienė \& Prijmenko, 2013). F pasižymi taip pat edukaciniu poveikiu, kai minèti holistiniai terapiniai aspektai susiejami su asmeninėmis ir socialinėmis vertybėmis: pripažistama vertybėmis grịsta sąveika, vykstanti mokymosi aplinkoje tarp F šokio mokytojo (šokio terapeuto) ir besimokančiujų (dalyvių) (Vargas, 2010). Tokia sąveika yra vadinama „veidrodinio atspindžio" terapine sąveika (Karkou, 2009; Hangendoorn, 2011). Neseniai Europos psichoterapeutai, tyrinejjantys AT, pripažino šio šokio poveiki kaip skatinantị asmenybės vystymąsi ir taip pat gydantị emocines traumas, depresiją ir socialinị nerimą (Polo, 2010; Salmons, 2014). Kadangi AT lyriškumas susipina su tragizmu ir ironija, tai leidžia tam tikra prasme atspindèti socialinių santykių gelmę poros (šeimos) socialinèse trajektorijose. Šokant AT, atsiranda galimybe improvizuoti, iš naujo užmegzti ryšius, bendrauti emociškai ir fiziškai, judèti drauge vykstant intymaus bendravimo procesui (Sartori \& Steidl, 2003). AT yra sudètinga meno forma, apimanti nenutrūkstamą emocinį dialogą su kitu, perduodamą per apkabinimus ir ¡̣kūnijamą per kūrybingą šokančiųjų choreografiją (Woodley \& Sotelano, 2011). Remiantis Dewey (1934/1980) ir Mearleau-Ponty (2002) darbais, konstruojamo tyrimo metodologija ir metodai apima teorines estetinès komunikacijos ir mokymosi teorijų vystymosi bei fenomenologinio tyrimo idejjas. Esminis dalykas yra tai, kad tyrimo metu atkreipiamas tiriamųjų dėmesys ị fenomenologinị kūno stebè- 
jimą ir ị socialinius pokyčius, kurie vyksta, kai žmogus kaip asmenybe keičiasi ir auga. Tiriant šokių poveikị metodologiniu požiūriu, svarbu tyrinèti savasties kitimą kaip savo gyvenimo praktini patyrimą, kuris yra asmens išgyvenimų ir suvokimų apibendrinantis (generalizuojantis) veiksnys (Whitehead \& McNiff, 2006). Todèl, metodologiniu požiūriu, svarbu analizuoti tiriamujų refleksijas apie jų subjektyviai suvokiamus išgyvenimus tyrimo metu (Whitehead, 2009). Specialus tyrinètojo dèmesys kreipiamas ị suvokimą ir jo dimensijas: savęs suvokimą, kito suvokimą, savo raiškos suvokimą ir savo vaidmens bei atsakingumo komunikuojant suvokimą. Šie teoriniai aspektai su praktiniu tyrimu susiejami per tyrinejjamą estetinès komunikacijos (Wickmam, 2017) raiškos patyrimą. Estetinès komunikacijos patyrimas igyjamas, tiek suvokiant save kaip atlikèją, šokejją, tiek stebint šokị (būnant auditorijos dalyviu). Skirtingų šokių skirtingos formalios charakteristikos paveikia stebėtojo subjektyvų patyrimą (Vukadinović, 2008). Metodologiškai nagrinėsime tris šokio, kaip estetinio patyrimo, charakteristikas (Vukadinović, 2010; Vukadinović \& Marković, 2012; Schindler et al., 2017) ir tirsime naudodami adaptuotą skalę pagal Andrews ir Withey (1976) šių charakteristikų koreliaciją su kūno emocinėmis identifikacijomis ir pasitenkinimu savo fizine, psichoemocine savijauta ir socialiniu bendravimu. Taikysime kiekybinius tyrimo metodus. Toliau aprašysime tyrimo instrumentus.

\section{Tyrimo instrumentai}

Bus naudojami keli tyrimo instrumentai.

Pirmasis tyrimo instrumentas. Siekiant nustatyti, kokị poveikị AT ir F šokiai turi fizinei, psichoemocinei ir socialinei savijautai, matuojamas prieš ir po šokio atlikimo ar stebejimo sesijos tiriamojo pasitenkinimas savijauta 7 taškų Likert skalèmis ir neverbaline priemone - adaptuota L. Sapežinskienès pagal Andrews ir Withey (1976) 7-ių veidų, išreiškiančių skirtingus jausmus, skale nuo A - labai patenkintas iki $\mathrm{G}$ - labai nepatenkintas (A - visiškai patenkintas; $\mathrm{B}$ - vidutiniškai patenkintas; C - šiek tiek patenkintas; D - neutralus; E - šiek tiek nepatenkintas; $\mathrm{F}$ - vidutiniškai nepatenkintas; $\mathrm{G}$ - visiškai nepatenkintas). Tyrimo dalyvis įrašo ị atitinkamą skiltị prieš AT ir F atlikimo (stebejjimo) sesiją ir po jos tokią raidę, kuri yra prie veido, kurio išraiška labiausiai atitinka jo subjektyvų pasitenkinimą fizine, psichoemocine ir socialine savijauta.

Antrasis tyrimo instrumentas. Tiriamuju estetinis ir emocinis patyrimas bus matuojamas 12-a 7 taškų Likert skalèmis. Instrumentas skirtas estetiniam atlikto ar stebèto šokio patyrimui, ịvertintam pagal tiriamujų subjektyvią estetinę patirtị, išmatuoti. Instrumentas apima 35 klausimus, sujungtus ị 3 veiksnių grupes: (1) estetinio patyrimo dinamiškumas (t. y. išraiškingumas, galingumas, stiprumas, jausmingumas); (2) estetinio patyrimo žavingumas (t. y. amžinumas, neapsakomumas, unikalumas, išskirtinumas); (3) estetinio patyrimo vertinimas (t. y. išraiškingumas, elegantiškumas, gundymas, emocionalumas) (Vukadinović, 2002; 2010; Vukadi- 
nović \& Marković, 2012; adaptuota L. Sapežinskienès). Kiekvienas iš 3 estetinio patyrimo veiksnių bus vertinamas keturiomis rango skalėmis. Tyrimo instrumentas buvo tris kartus išverstas profesionalių vertejų (iš anglų $k$. j̣ lietuvių kalbą ir vẻl $-i$ anglų k., ir pakoregavus atitinkamai - ị lietuvių kalbą). Tiriamieji užpildys estetinio patyrimo anketą, kiekvienoje skalejje pažymėdami po vieną matmenį (nuo 1 (mažas) iki 4 (labai didelis), atitinkantị jų subjektyvų estetinị patyrimą, igytą šokant ar stebint AT / F vaizdo įrašus.

\section{Tiriamieji ir tyrimo procedūra}

Tiriamieji - karinis personalas, patyręs trauminius įvykius (dalyvavęs kovose, misijose ir pan., kuriam diagnozuotas arba nediagnozuotas potrauminis streso sindromas), nuo 18 iki 70 metų bus pakviestas savanoriškai dalyvauti tyrime, prieš tai supažindinus su tyrimo informacine anketa (tyrimo tikslais, uždaviniais ir procedūra, etiniais dalyvavimo tyrime kriterijais) ir ją pasirašius. Planuojama ịtraukti apie 60 tiriamujų ir padalinti ị šokančiųų ir stebinčiųjų šokị grupes. Tiriamiesiems prieš ir po kiekvienos šokio atlikimo ar stebejjimo sesijos bus pateikiami aukščiau aprašyti tyrimo instrumentai. Tyrimo dalyviai atsitiktiniu būdu bus padalinti ị dvi grupes - šokančiujų arba stebinčiujų AT ir F. AT ir F atlikimo sesijos truks 45 min. 2 kartus per savaitę, vieną mėnesį - iš viso 8 sesijos. Stebètojams bus vieną kartą parodyti AT ir F vaizdo filmai. Vienos sesijos trukmè - 60 min. Klausimynų pildymo trukmè - 15 min. Tyrimą vykdys apmokyti tyrejjai ir asmenys, galintys taikyti AT ir F psichoterapinejje ar edukacinėje veikloje (pavyzdžiui, psichoterapeutas, socialinis darbuotojas, šokio mokytojas ar šokio - judesio terapeutas). Tyrimo duomenys bus apdoroti taikant SPPS programas.

\section{Rezultatai ir išvados}

Straipsnyje pateikta tyrimo metodologija skirta atsakyti ị mokslinio tyrimo klausimą: koks karinio personalo, patyrusio stresinius, trauminius įvykius, estetinis ir emocinis patyrimas, kai jis atlieka ar stebi AT ir F reabilitacijos ir (ar) edukaciniais tikslais? Metodologija ir metodai aprašyti ir moksliškai pagrịsti. Aprašyti tyrimo metodai ir tyrimo instrumentai skirti nustatyti, kokị poveikị AT ir F turi tyrimo dalyvių pasitenkinimui savo fizine, psichoemocine ir socialine savijauta ir jų estetinio ir emocinio patyrimo vertinimui po šių šokių atlikimo ar stebejjimo. Kadangi skirtingos šokių formos (AT, F) veikia subjektyvų estetinị šiuos šokius stebinčių dalyvių patyrimą (Vukadinović, 2008) ir yra identifikuojami trys estetinio patyrimo veiksniai šoki atliekantiems ir stebintiems (Vukadinović, 2010; Vukadinović \& Marković, 2012), tikètina koreliacija tarp estetinio šokio patyrimo ir emocinès identifikacijos ir pasitenkinimo savo fizine, psichoemocine ir socialine savijauta. Parengta metodologija tinkama naudoti tyrimui atlikti. 


\section{Literatūra}

Andrews, F. M. and Withey, S.B. (1976). Social Indicators of Well-being: Americans', Perceptions of Life Quality Plenum, New York: Plenum.

Burrell, L., Gary, A., Doris, A., Durand, B., Carl Andrew, C., Carl, C. \& Castro, A. (2006). The Impact of Military Lifestyle Demands on Well-being, Army, and Family Outcomes. Armed Forces \& Society 33(1): 43-58.

Caltabiano, P. A. (2009). Embodied Identities: Negotiating the Self through Flamenco Dance Theses Department of Anthropology, Georgia State University. The Columbia Encyclopedia, 6th ed. $\mid 2012$ | Copyright.

The Context of Military Environments: An Agenda for Basic Research on Social and Organizational Factors Relevant to Small Units (2014) Washington: The National Academies Press. www.nap.edu

Dewey, J. (1934/1980). Art as Experience. New York: Perigee Books. (Originally published 1934.)

Hatch, S. L., Harvey, S. B., Dandeker, C., Burdett, H., Greenberg, N., Fear, N. T., et al. (2013). Life in and after the Armed Forces: Social Networks and Mental Health in the UK Military. Sociology of Health \& Illness, 35(7): 1045-1064.

Hangendoorn, I. (2011). Dance, Choreography and the Brain. In Melcher, D. and Bacci F. (eds). Art and the Senses. Oxford: Oxford University Press, (pp. 499514). Iversen, A., van Staden, L., Hughes, J., Browne, T., Hull, L., Hall, J., et al. (2009). The Prevalence of Common Mental Disorders and PTSD in the UK Military: Using Data from a Clinical Interview-Based Study. BMC Psychiatry, 9-68.

Iversen, A. C., van Staden, L., Hughes, J. H., Browne, T., Greenberg, N., Hotopf, M., et al. (2010). Help-seeking and receipt of treatment among UK service personnel. The British Journal of Psychiatry, 197: 149-155.

Karkou, V. (2009). Forming therapeutic relationships in Dance Movement Psychotherapy: The Role of Mirroring. Interdisciplinary Panel 2: Kinesthetic Experience and Embodied Practices.

Koch, S. C., Wirtz, G., Christian Harter, Ch., Weisbrod, M., Winkler, F., Pröger, A., \& Herpertz, S.C. (2019). Embodied Self in Trauma and Self-harm: Effects of Flamenco Therapy on Traumatized in-Patients. A pilot study1 Article in Journal of Loss and Trauma.

Mearleau-Ponty, M. (2002). The Phenomenology of Perception. London: Routledge and Keegan.

Polo, G. (2010). The Space Between Us: The Experience of Relationship in the Argentine Tango. Dance/Movement Therapy \& Counseling Theses. Paper 14.

Prijmenko, A. (2013). „Duende“ diskursas istorineje flamenko šokio stiliaus raiškoje. Magistro mokslinis baigiamasis darbas. Klaipėdos universitetas, Menu fakultetas, Choreografijos katedra. Vadovè T. Zinčiukienè.

Ramirez, J., Erlyana, E. \& Guilliaum, M. (2016). A Review of Art Therapy Among Military Service Members and Veterans with Post-Traumatic Stress 
Disorder. Journal of Military and Veterans' Health, 24(2).

Salmons, C. A. (2014). Dance for your Life! TangoFlow! ${ }^{\circledR}$ Technique and Implications in the Treatment of Trauma. A Mixed-methods Empirical Study Based upon Independent Investigation. Submitted in partial fulfillment of the requirements for the degree of Master of Social Work. Catherine A. Salmons Smith College School for Social Work. Northampton, Massachusetts 01063.

Sapežinskienè, L., Prijmenko, A. (2013). Flamenko gydomoji galia. Nervų ir psichikos ligos. Specializuotas leidinys gydytojams. 2013 m. Nr. 1 (60), p. 33-35.

Sartori, R., Steidl, P. (2003). Tango: šokio erotinio prado galia. Vilnius: Tyto Alba.

Sevdalis, V. \& Keller, P. E. (2011). Captured by Motion: Dance, Action Understanding and Social Cognition. Brain and Cognition, 77: 231-236.

Schindler I., Hosoya G., Menninghaus W., Beermann U., Wagner V., Eid M., et al. (2017). Measuring Aesthetic Emotions: A Review of the Literature and a New Assessment Tool. PLoS ONE 12(6): e0178899. https://doi.org/10.1371/journal. pone.0178899

Vargas, L. (2010). Flamenco Dance as Education (al). Conference Action Research: Exploring its Transformative Potential. 19 August - Friday 20 August 2010, University of Kwa Zulu Natal. Faculty of Education: Nelson Mandela Metropolitan University.vargas@telkomsa.net

Vukadinović, M. (2002). Flamenko - Između Tišine I Usklika. [Flamenco Between Silence and Scream]. Novi Sad: Futura.

Vukadinović, M. (2008). Subjektivni doživljaj različitih tipova umetničke igre. [Subjective Experience of Different Types of Artistic Dance]. Unpublished Master's Thesis, Belgrade University.

Vukadinović, M. (2010). Odnos estetskog doživljaja plesača I estetskog doživljaja publike. [Relation between Aesthetic Experience of a Dancer and Aesthetic Experience of Audience]. Unpublished PhD Thesis, Belgrade University.

Vukadinović, M., Marković, S. (2011). Aesthetic Experience of Dance Performances. Psihologija, 45(1): 23-41.

Vukadinović, M., Markovič, S. (2012). Aesthetic Experience of Dance Performances. Psihologija. 2012; 45(1):23 \pm 41 . https://doi.org/10.2298/ PSI1201023V

Wickmam, P. O. (2017). Back to the Drawing Board: Examining the Philosophical Foundations of Educational Research on Aesthetics and Emotions. In Bellocchi, A., Quigley, C., \& Otrel-Cass, K. (Ed.). Exploring Emotions, Aesthetics and Well-being in Science Education Research. Switzerland: Springer. (PP. 9-38).

Whitehead, J., McNiff, J. (2006). Action Research Living Theory. London: Sage.

Whitehead, J. (2009). How do I Influence the Generation of Living Educational Theories for Personal and Social Accountability in Improving Practice? Using a Living Theory Methodology in Improving Educational Practice. Paper presented at 
the SeStuTHE \& ECP @ CELT @ DUT, Durban University ofTechnology Durban, December 7-14.

Winters, A. (2017). How I Learned to Use Dance/Movement Therapy to Help Military Veterans. Saybrook Forum, Creativity \& Innovation, Human Experience, Mind-Body Medicine, Therapeutic Practices. (Tuesday, February 21, 2017). https:// www.saybrook.edu/unbound/journey-learned-use-dancemovement-therapy-helpmilitary-veterans/

Woodley, K. \& Sotelano, M. (2011). Tango Therapy. Research and Practice. London: Tango Creations Publishers. 


\title{
METHODOLOGY OF THE IMPACT OF ARGENTINE TANGO AND FLAMENCO DANCES: AESTHETIC AND EMOTIONAL EXPERIENCE OF MILITARY PERSONNEL
}

\author{
Dr. Laima Sapežinskienė \\ Lithuanian University of Health Sciences \\ Jurgita Kuliešienè \\ Independent researcher
}

\section{Summary}

The aim of the publication is to present the methodology of the research that is based on the scientific data results that "dance has aesthetical impact not only onto the performers of the dance, but also observers (audience)" (Vukadinović, 2010; Vukadinović \& Marković, 2011). Research problem: it is an evidence-based research that dance and dance movement develop brain activity and neuroplasticity. Also, it has been scientifically proven that when dancing aesthetical experience of movement and dance is felt via proprioception senses in the body: muscles, tendons and joints, i.e. in the kinesthetic and vestibular system (Vukadinović \&Marković, 2011). Nevertheless, it is not clear if it is valuable to use dance observation and not only dancing in the rehabilitation process of the military personnel. Research question: what is the aesthetic and emotional experience of the military personnel which have experienced stressful and traumatic events when they perform or observe Argentine Tango and Flamenco dances for rehabilitation and/ or educational purposes? Novelty. Until the research, it was not found that similar or the same methodology was applied for military personnel after stressful or traumatic events for rehabilitation and/or education. In order to answer the methodological aspects of self and others, self-expression, responsibility, communication and own role are joined together using the study of aesthetic communication experience (Wickmam, 2017) that is gained precepting self as a dance performer and observing a dance itself as an audience. Methodological concept specifically includes three characteristics of the dance as aesthetic experience (Vukadinović, 2010; Vukadinović \& Marković, 2012; Schindler et al., 2017) and their correlation with body emotional identifications and satisfaction scale of physical, psychoemotional and social well-being adapted from Andrews and Withey (1976). It is intended to apply quantitative research methods. Objectives: 1) to develop a research methodology; 2) to describe a research instrument which could be applied for identification of the impact Argentine Tango and Flamenco dances have on physical, psychoemotional and social well-being of the research participants before and after observation of these dances; 3 ) to find correlations among aesthetic dance experience, emotional identification and satisfaction of individual physical, psychoemotional and social well-being. Research object: it is planned to recruit around 60 participants aged between 18 and 70 years old who are members of military personnel and have experienced traumatic events (participated in combats, military missions, etc.) with diagnosed or not post-traumatic stress syndrome. All the research participants will be acquainted with the information questionnaire of the 
research and will decide themselves whether they want to participate in the research or not. Results and conclusions. The publication presents the research methodology which is intended to answer the following scientific research question: what is the aesthetic and emotional experience of the military personnel who experienced stressful and traumatic events when they perform or observe Argentine Tango and Flamenco dances for rehabilitation and/or educational purposes? Methodological concept is described and scientifically based. Described research methods and instruments are intended to define what impact Argentine Tango and Flamenco dances have on the satisfaction of the research participants with their physical, psychoemotional and social well-being as well as the evaluation of their aesthetic and emotional experience after performing or observing the dances. As different dance types have an impact on the subjective aesthetic experience of the dance observers (Vukadinović, 2008) and three aesthetic experience factors are identified when performing and observing the dances (Vukadinović, 2010; Vukadinović \& Marković, 2012), it is very likely that there is a correlation among aesthetic dance experience, emotional identification and satisfaction of the individual physical, psychoemotional and social well-being. Developed methodology is appropriate for the use in the research.

Key concepts: Military Personnel, Aesthetic and Emotional Experience, Argentine Tango (AT), Flamenco (F), Satisfaction with Well-being. 


\section{AUTORIŲ LYDRAŠTIS}

Autoriaus vardas, pavardė: Laima Sapežinskienè

Mokslo laipsnis ir vardas: socialinių mokslų (organizacijų sociologija) daktare

Darbo vieta ir pareigos: Lietuvos sveikatos mokslų universitetas, Medicinos akademija, Neuromokslų institutas, Elgesio medicinos laboratorija, Šliūpo g. 7, Palanga, Lietuva; mokslo darbuotoja

Autoriaus mokslinių interesų sritys: dalyvavimas mokslinių tyrimų projektuose, susijusiuose su trauminių patirčių ir psichosomatinių sveikatos problemų tyrinèjimu, psichoterapijos ir šokio - judesio psichoterapijos veiksmingumo, organizacinių pokyčių komandos ir organizacijos organizacinès kaitos tyrimais

Telefonas ir el. pašto adresas: +37061414 543,

marija1000@gmail.com; laima.sapezinskiene@1smuni.lt

Autoriaus vardas, pavardè: Jurgita Kuliešienè

Mokslo laipsnis ir vardas: nèra

Darbo vieta ir pareigos: nepriklausoma tyreja

Autoriaus mokslinių interesų sritys: dalyvavimas mokslinių tyrimų projektuose, susijusiuose su trauminių patirčių ir psichosomatinių sveikatos problemų tyrinèjimu

Telefonas ir el. pašto adresas: +370 61622 166, jurga.kuliesiene@gmail.com

\section{AUTHORS’ COVER LETTER}

Author's name and surname: Laima Sapežinskienė Sociology)

Academic degree and name: Doctor of Social Sciences (Organization

Workplace and position: Lithuanian University of Health Sciences, Medical Academy, Neurosciences Institute, Behavioral Medicine Laboratory, Researcher.

Author's research interests: participation in the research projects relating to the exploration of traumatic experiences and psychosomatic health problems, effectiveness of psychotherapy and dance movement psychotherapy, efficiency of organizational changes of teams and organisations

Telephone and e-mail address: +37061414 543, marija1000@gmail.com, laima.sapezinskiene@1smuni.lt

Author's name and surname: Jurgita Kuliešienè Workplace and position: independent researcher

Author's research interests: participation in the research projects relating to the exploration of traumatic experiences and psychosomatic health problems

Telephone and e-mail address: +370 61622 166, jurga.kuliesiene@gmail.com 